УДК 93

DOI $10.21661 / r-119031$

\title{
В.Н. Панов
}

\section{УЧРЕДИТЕЛЬНОЕ СОБРАНИЕ ИЛИ ВЛАСТЬ СОВЕТОВ: ПРОБЛЕМА ВЫБОРА ПУТИ РАЗВИТИЯ РОССИИ В 1917 Г.}

Аннотация: в статье рассматривается период политической борьбы в России с февраля 1917 г. по январь 1918 г., когда решался вопрос о политическом будущем России. В статье рассматриваются вопросы отношений между Временным правительством и Советом рабочих и солдатских депутатов. Особое внимание уделяется деятельности Временного правительства по подготовке Учредительного собрания и выработке проектов будущей конституции России. Автор статьи анализирует причинь, не позволившие реализовать демократический либерально-буржуазный путь развития России, и победы советской модели политического развития.

Ключевые слова: Временное правительство, Совет рабочих и солдатских депутатов, двоевластие, Учредительное собрание, юридическое совещание, особое совещание, особая комиссия, демократическое совещание, предпарламент.

\section{V.N. Panov}

\section{CONSTITUENT ASSEMBLY OR SOVIET POWER: THE PROBLEM OF CHOOSING THE PATH OF DEVELOPMENT OF RUSSIA IN 1917}

Abstract: the article examines the period of political struggle in Russia from February 1917 to January 1918, when it was a question of the political future of Russia. The article discusses the relations between the Provisional government and the Soviet of workers "and soldiers" deputies. Special attention is paid to the activities of the Interim government on the preparation of the Constituent Assembly and the drafting of the future Constitution of Russia. The author of the article analyzes the reasons, not allowed to implement democratic liberal-bourgeois way of development of Russia, and the victory of the Soviet model of political development. 
Keywords: provisional government, the Soviet of workers "and soldiers" deputies, the dual power, Constituent Assembly, legal meeting, special meeting, special commission, Democratic conference, the pre-Parliament.

Впервые требование Учредительного собрания (Великого собора) в первой четверти XIX в. выдвинули декабристы. Во второй половине XIX в. идея созыва Учредительного собрания (Земского собора) нашла отражение у революционных демократов и революционных народников. Важное место этот вопрос занимал в программах земских конституционалистов - либералов второй половины XIX - начала XX вв. В начале XX в. требование созыва Учредительного собрания получило закрепление в программах политических партий, как социалистического (РСДРП, эсеров), так и либерально-буржуазного толка (кадеты). Особенно широко требование созыва Учредительного собрания получило распространение в российском обществе в годы революции 1905-1907 гг. Даже в петиции шествия к царю 9 января 1905 г. прозвучало: «Немедленно повели созвать представителей земли русской... Повели, чтобы выборы в Учредительное Собрание происходили при условии всеобщей, тайной и равной подачи голосов» $[14$, с. 85$]$. В.И. Ленин считал, что «в буржуазной республике Учредительное собрание является высшей формой демократизма» [10, с. 162].

В условиях 1917 г. популярность лозунга созыва Учредительного собрания в значительной степени объяснялась тем, что практически все слои русского общества связывали с Учредительным собранием свои надежды на решение важнейших политических и социально-экономических проблем России: решение вопроса войны и мира, политического будущего России, решение рабочего, аграрного и национального вопросов. Причем каждая партия, каждый слой населения страны по-своему понимали и видели решение этих вопросов будущим Учредительным собранием.

Если идея Учредительного собрания имела долгие теоретические традиции, то Советы как органы революционного народовластия, возникнув в мае 1905 г. в период первой русской революции, приобрели, хотя и за короткий срок существования, практический опыт организации народных масс. В годы 
революции 1905-1907 гг. Советы, возникшие как результат политического творчества народных масс, получили широкое распространение. Впервые возникнув в мае 1905 г. в Иваново-Вознесенске, уже «в октябре-декабре 1905 г. Советы рабочих депутатов действовали более чем в 50 городах и рабочих поселках» [11, с. 117]. Помимо Советов рабочих депутатов формировались «советы солдатских (Москва), казачьих (Чита), матросских (Севастополь). крестьянских депутатов и др. [14, с. 89]. В период Февральской революции 1917 г. Советы получили второе дыхание и приобрели всероссийский характер. Эти две идеи (Учредительное собрание и Советы), выражавшие две концепции будущего политического развития России, после непродолжительного сотрудничества в 1917 г., вошли в противоречие друг с другом и привели к роспуску Учредительного собрания в январе 1918 г.

В феврале 1917 г. в России произошла революция, итогом которой стало отречение Николая II от престола. 2 марта 1917 г. Николай II отрекся от престола в пользу Великого князя Михаила. Михаил, в свою очередь, 3 марта отказался от престола, оставив решение вопроса о форме правления в России на усмотрение российского народа через решение Учредительного собрания. Таким образом, вопрос о будущей форме политического правления в России остался открытым. Неопределенность возникла и по вопросу организации власти в переходный период. Еще 27 февраля 1917 г. в разгар революции возникли две формы организации новой власти в России: Петроградский Совет рабочих и солдатских депутатов, в который вошли представители партий социалистического выбора (меньшевики, эсеры, большевики), и, Временный комитет Государственной Думы, по инициативе которого 2 марта 1917 г. было создано из представителей буржуазных партий кадетов и октябристов Временное правительство во главе с князем Г.Е. Львовым. Состав и программа Временного правительства были согласованы в ходе переговоров Временного комитета Государственной думы и Исполнительного комитета Петроградского совета. Несмотря на это в стране установилось двоевластие, которое свидетельствовало о расколе политических сил и общества по партийному и классовому принципу. 
Чтобы преодолеть этот раскол меньшевистско-эсеровское руководство Петроградским советом заключило соглашение с Временным комитетом Государственной Думы о подготовке и созыве Учредительного собрания для решения вопросов будущего России.

Для понимания важности этого компромисса между Временным правительством и Петроградским советом следует обратить внимание на расстановку классовых и политических сил в стране после Февральской революции. Современники оценивали эту расстановку следующим образом: «Советы сила - без власти, Временное правительство власть - без силы». Советы являлись выборными представительными органами рабочих, солдат и крестьян. Советы также выступали за созыв Учредительного собрания. В 1917 г. произошло объединение Советов на всероссийском уровне. В мае 1917 г. состоялся I Всероссийский съезд Советов крестьянских депутатов, а в июне 1917 г. прошел I Всероссийский съезд Советов рабочих и солдатских депутатов. В работе I Всероссийского съезда Советов рабочих и солдатских депутатов приняли участие 1090 делегатов от 400 местных Советов рабочих и солдатских организаций. На съезде был избран Всероссийский Центральный Исполнительный Комитет (ВЦИК), в котором подавляющее большинство имели партии меньшевиков и эсеров, проводившие соглашательскую политику в отношении Временного правительства.

За Советами стояла основная масса населения России, мелкобуржуазной по своему социально-классовому составу, где около 80\% населения составляло крестьянство. В годы первой мировой войны возросла роль 15 миллионной армии в общественно-политической жизни страны. Приказ №1 от 1 марта 1917 г. поставил армию под контроль Советов. В условиях войны резко вырос радикализм в настроениях широких слоев населения, которое требовало немедленного решения важнейших политических и социально-экономических вопросов: вопроса войны и мира, будущего политического устройства России, рабочего, крестьянского, национального. Весь предшествующий опыт взаимоотношений между властью и обществом стал наглядным примером противостояния 
между ними, невозможности каких- либо политических компромиссов. Этот опыт переносился и нашел отражение в событиях 1917 г.

В свою очередь, русская буржуазия была относительно слаба в политическом, социальном и экономическом отношении, традиции русского либерализма были недостаточно развиты и не проникли в сознание широких слоев населения. В общественном сознании преобладали антизападные, анти буржуазные, социалистические, общинные, уравнительные настроения. В таких условиях приходилось действовать Временному правительству - приверженцу западного варианта пути развития России. Практически весь период с марта по октябрь 1917 г. был периодом политического кризиса власти, у руля которой стояло Временное правительство. Только поддержка и подпитка со стороны партий умеренных социалистов (меньшевиков и эсеров), которые имели большинство в руководстве Исполкома Петроградского совета, дала возможность Временному правительству быть у власти с марта по октябрь 1917г.

В деятельности Временного правительства можно выделить несколько периодов: март - апрель 1917 г. - деятельность Временного правительства первого состава. Апрель 1917 г. - первый кризис Временного правительства. Май июнь 1917 г. формирование и деятельность первого коалиционного правительства с участием меньшевиков и эсеров. Июль 1917 г. - кризис первого коалиционного правительства. Июль - август 1917 г. формирование и работа второго коалиционного правительства под руководством А.Ф. Керенского. Сентябрь 1917 г. - кризис второго коалиционного правительства. Создание Директории. 25 сентября - 25 октября 1917 г. формирование и деятельность третьего коалиционного правительства.

И без того острую политическую ситуацию в стране обостряла борьба партии большевиков во главе с В.И. Лениным за дальнейшее развитие революции по пути перерастания Февральской буржуазно-демократической революции в социалистическую революцию. Главным инструментом борьбы стало противопоставление власти Временного правительства власти Советов. В своей работе «Апрельские тезисы» В.И. Ленин сформулировал два основополагающих ло- 
зунга этой борьбы в условиях двоевластия: «Вся власть Советам», «Никакой поддержки Временному правительству». В.И. Ленин считал, что реализовать эти лозунги в условиях двоевластия можно мирным путем, стоит лишь Советам прекратить поддержку Временного правительства. Переход власти Советам В.И. Ленин рассматривал как завершение этапа демократической революции и формирование революционно-демократической диктатуры пролетариата и крестьянства, с последующим переходом к социалистической революции.

Одновременно с этим, В.И. Ленин, не отвергая идеи созыва Учредительного собрания, в то же время отдавал предпочтение Советам как будущим органам народовластия. «Выставляя требование созыва Учредительного собрания, революционная социал-демократия с самого начала революции 1917 года неоднократно подчеркивала, что республика Советов является более высокой формой демократизма, чем обычная буржуазная республика с Учредительным собранием» [10, с. 162].

Вот в таких непростых условиях Временное правительство попыталось осуществить подготовку к проведению Учредительного собрания. 3 марта 1917 г. была опубликована Декларация Временного правительства, ставшая программой его деятельности. Важнейшими пунктами этой программы стали: «Выборы в органы местного самоуправления на основе всеобщего прямого равного и тайного голосования» и «Немедленная подготовка к созыву на началах всеобщего, равного, прямого и тайного голосования Учредительного собрания, которое установит форму правления и конституцию страны» [1].

Эти две задачи были взаимосвязаны, поскольку практическая подготовка и проведение Всероссийских выборов в Учредительное собрание во многом зависело от организации и эффективности работы местных органов самоуправления. Было сформировано правительственное совещание по реформе местного управления. 15 апреля 1917 года Временное правительство опубликовало «Положение о производстве выборов гласных городских дум и об участковых городских управах», определившее численность гласных и полный перечень муниципалитетов 453 городов России, в которых необходимо провести выборы на 
основе всеобщего избирательного права. Закон 21 мая 1917 г. ввел всеобщие, прямые, равные выборы при тайной подаче голосов. В июле- сентябре 1917 года выборы состоялись на территории всей страны. К осени 1917 года были сформированы новые органы местного самоуправления, которые активно участвовали в организации и проведении выборов в Учредительное собрание.

Постановлением Временного правительства, от 22 марта 1917 г., было создано Юридическое совещание в обязанности которого входила подготовка и проведение выборов в Учредительное собрание. 26 марта 1917 г. вышло Постановление Временного правительства об образовании Особого совещания для подготовки проекта Положения о выборах в Учредительное собрание. Особое совещание по подготовке закона о выборах в Учредительное собрание возглавил Ф.Ф. Кокошин. Не остался в стороне от процесса подготовки Учредительного собрания и Исполком Петроградского Совета. В конце марта он создал комиссию по выборам в Учредительное собрание, которую возглавил Л.М. Брамсон. В нее вошли В.В. Водовозов, В.Б. Станкевич. На пленарном заседании Особого совещания 14 июня 1917 г. присутствовали представители Советов [16].

Результатом работы Особого совещания стало Постановление Временного правительства от 20 июля 1917 г. «Об утверждении положения о выборах в Учредительное собрание». «Положение о выборах в Учредительное собрание» вводило избирательное право на основе всеобего, равного, тайного и прямого голосования. «Право участия в выборах в Учредительное собрание имеют российские граждане обоего пола, коим исполнится 20 лет. Право участия в выборах имеют лишь лица, внесенные в избирательный список участка. Право быть избираемым в каждом избирательном округе имеет каждое лицо, пользующееся правом участия в выборах.

По «Положению о выборах в Учредительное собрание» избирательных прав лишались признанные в установленном порядке сумасшедшими, глухонемые, находящиеся под опекой, осужденные судебными приговорами, члены царствовавшего в России дома Романовых. 
Заведывание производством выборов возлагалось на: 1) Всероссийскую, окружные, столичные, уездные и городские по делам о выборах в Учредительное собрание комиссии и участковые избирательные комиссии и 2) городские и поселковые управы и волостные земские управы. На Всероссийскую по делам о выборах в Учредительное собрание комиссию возлагалось: общее наблюдение за ходом выборов в Учредительное собрание; выработка утверждаемых Временным правительством общих инструкций; составление списка лиц, избранных в члены Учредительного собрания; обработка статистических и иных данных по выборам в Учредительное собрание. Положение о выборах регламентировало порядок, время и сроки проведения выборов» [5]. Постановлением от 26 июля 1917 г. - на Юридическое совещание были возложены «подготовительные работы, связанные с открытием Учредительного собрания».

В октябре 1917 года была образована Особая комиссия по составлению проекта Основных законов (Конституции). В состав этой комиссии, возглавляемой профессором Н.И. Лазаревским, входило около 30 юристов и общественных деятелей. Комиссия приступила к работе 11 октября 1917 года. К 20 октября 1917 года конституционный проект в основном был составлен. В основу проекта, составителями были заложены три основные идеи: торжество народного верховенства, развитие местного самоуправления, широкие политические права и свободы граждан. Особая комиссия подготовила проекты законов: о гражданах Российской республики, об автономии и федерации, об однопалатной и двухпалатной системах, о статусе прав гражданина, был обсужден проект Декларации прав гражданина. Важное место занимал проект «О временной исполнительной власти» (О временном президенте).

Среди разработанных проектов выделялись: «Об организации временной исполнительной власти при Учредительном собрании», «Тезисы по вопросу о верхней палате», статьи «Основных законов по вопросу об автономии». Особая комиссия выработала очень важный для многонациональной России предварительный проект статей по вопросу об автономии. В соответствии со статьями проекта «Основных законов по вопросу об автономии» «Государство Россий- 
ское провозглашалось едино и неделимо. В Государстве Российском предполагалось введение областной автономии. Предполагался приоритет общегосударственных законов над местными». Проект документа «Тезисы по вопросу о верхней палате» предполагал создание двухпалатного парламента в России с законодательными полномочиями [12].

Проект документа «Об организации временной исполнительной власти при Учредительном собрании» являлся «малой конституцией» Временного правительства. Согласно проекту: Россия объявлялась республикой во главе с президентом, избираемым Учредительным собранием; предполагалось создать двухпалатный парламент. Президент обладал широкими полномочиями, и, в какой-то степени, его права напоминали права императора, закрепленные в Основных законах Российской империи 23 апреля 1906 г.

Временный президент должен был осуществлять свои полномочия под «надзором Учредительного собрания и при содействии Совета Министров». Президент «наделяется правом законодательной инициативы» - законопроекты вносятся на рассмотрение Учредительного собрания Советом Министром от имени президента. Президент «наблюдает за исполнением законов и делает распоряжения, издает указы об устройстве, составе и порядке действий правительственных учреждений. Президент «руководит внешними сношениями». Президенту «принадлежит верховное начальствование над всеми вооруженными силами...». Президент мог назначать и увольнять «председателя Совета Министров и министров. Ответственность перед Учредительным собранием за «общий ход государственного управления» возлагалась не на президента, а на председателя Совета Министров и отдельных министров.

Временный президент согласно этой юридической формуле мог всегда переложить свою ответственность на министров, оставаясь вне всякой реальной ответственности. Речь шла о формировании президентской Российской республики, где президент сосредоточивал в своих руках все нити и руководящие центры государственного управления [15]. 
В соответствии с разработанными проектами законов Россия должна была стать единым нераздельным государством, президентской республикой, с двухпалатным законодательным парламентом и ответственным перед Учредительным собранием Советом министров. В выработанных законопроектах в определенной степени прослеживалась преемственность конституционных принципов Основных законов 1906 г. «Конституция», которую Временное правительство хотело оформить на Учредительном собрании, была призвана закрепить в России государственный строй в форме «единой и неделимой» парламентарной республики президентского типа [12].

Временное правительство, решением от 14 июня 1917 г., назначило выборы на 17 сентября, а созыв Учредительного собрания на 30 сентября 1917 г. Позднее эти сроки были перенесены соответственно на 12 и 28 ноября 1917 г. Тем самым было упущено время и исторический шанс политического развития России по западноевропейскому демократическому пути.

Пик работы по подготовке проведения Учредительного собрания и выработке конституционных проектов проходил в условиях обострения политического кризиса в стране, приведшего к отставке второго коалиционного правительства и созданию Директории. В конце августа- начале сентября 1917 г. произошла «большевизация» столичных Советов, проголосовавших за ленинский лозунг «Вся власть Советам». В целях преодоления политического кризиса 1 сентября 1917 г. Россия была объявлена республикой. ЦИК Советов рабочих и солдатских депутатов и Исполком Советов крестьянских депутатов 1 сентября 1917г. приняли решение созвать Демократическое совещание для поиска гражданского согласия. Демократическое совещание проходило 1422 сентября 1917 в Петрограде. В нем участвовали 1582 делегата от Советов рабочих депутатов, Советов крестьянских депутатов, общественных организаций. Партийный состав делегатов выглядел следующим образом: 532 эсера, 172 меньшевика, 136 большевиков, 400 беспартийных делегатов и др. На Демократическом совещании прозвучала идея отказа умеренных социалистов от коалиции с кадетами и создание социалистического однородного правительства. 
Демократическое совещание приняло решение об образовании Временного Совета Российской республики (Предпарламента) с правом контроля правительства до созыва Учредительного собрания. Во время работы Демократического совещания были возможны три варианта промежуточного решения вопроса о власти: создание нового коалиционного Временного правительства; превращение в источник власти Демократического совещания (предпарламент) и формирование ответственного перед ним правительства (однородное социалистическое правительство); формирование правительства Всероссийским съездом Советов. Был избран первый вариант выхода из политического кризиса. 25 сентября 1917 г. формируется третье коалиционное правительство во главе с А.Ф. Керенским.

Несмотря на сложность политической ситуации в стране, практическая деятельность по подготовке Учредительного собрания шла непрерывно. С 7 (20) августа 1917 начались заседания Всероссийской комиссии по делам о выборах в Учредительное собрание. В сентябре 1917 г. приступили к составлению списков избирателей. В октябре 1917 г. опубликованы кандидатские списки политических партий. Даже свержение Временного правительства и приход к власти большевиков не смогли остановить процесс подготовки к проведению выборов в Учредительное собрание. В принятом на II Всероссийском съезде Советов 26 октября (8 ноября) обращении «Рабочим, солдатам и крестьянам было подчеркнуто: «Советская власть...обеспечит своевременный созыв Учредительного собрания» [3] В Постановлении об образовании рабочего и крестьянского правительства отмечалось: «Образовать для управления страной, впредь до созыва Учредительного собрания, временное рабочее и крестьянское правительство, которое будет именоваться Советом Народных Комиссаров» [7].

Выборы в Учредительное собрание проходили с 12(25) ноября 1917 до января 1918 г. В голосовании, по данным 65 округов, участвовало 45 млн. избирателей (всего было 79 округов и в них 90 млн. избирателей). За эсеров проголосовало около $40,4 \%$ избирателей, за большевиков - $25 \%$, за кадетов - $5 \%$, за меньшевиков - около 3\%. Всего было избрано 715 депутатов. Однако ко дню 
открытия Учредительного собрания, 28 ноября 1917 г., вместо ожидаемых 500600 депутатов были избраны лишь 173, а приехать в Петроград смогли лишь 100 человек.

В связи с этим Совет народных комиссаров декретом от 26 ноября установил, что открытие Учредительного собрания возможно при наличии 400 депутатов. «Согласно декрету Совета Народных Комиссаров, утвержденному Центральным Исполнительным Комитетом Советов, Учредительное собрание будет созвано, как только половина членов Учредительного собрания, именно 400 депутатов, зарегистрируется установленным образом в канцелярии Таврического дворца» [7, с. 149]. На многочисленные запросы, когда откроется Учредительное собрание, глава советского правительства В.И. Ленин отвечал: «Не занимайтесь чтением в сердцах, мы ничего не скрываем. Мы сказали, когда будут 400 человек, мы Учредительное собрание созовем. Не мы виноваты, что выборы состоялись позже, чем были назначены» [8, с. 136].

С юридической точки зрения В.И. Ленин был прав, так как в условиях отсутствия кворума, когда еще шел процесс выборов в Учредительное собрание, любое решение, принятое собравшимися членами Учредительного собрания, имело бы нелегитимный характер. Однако политические противники большевиков не хотели ждать кворума и горели желанием политического реванша. Под лозунгом Учредительного собрания 28 ноября, в день его созыва, в Петрограде прошла демонстрация кадетов и правых эсеров. В ответ Советское правительство в тот же день, 28 ноября, издало декрет об аресте вождей гражданской войны против революции и объявило партию кадетов врагами народа. Были арестованы кадетские депутаты Ф.Ф. Кокошин, А. Шингарев, П. Долгоруков, немного позднее правые эсеры Н.А. Авксентьев, А. Аргунов, В. Филипповский.

Конечно, откладывая созыв Учредительного собрания, В.И. Ленин руководствовался не только отсутствием кворума, но и партийным составом самого Учредительного собрания, где большевики оказались в меньшинстве. Это создавало угрозу власти большевиков. Важным обстоятельством был и тот факт, что Россия после событий октября 1917 г., фактически оказалась в состоянии 
Гражданской войны. В.И. Ленин писал: «Если брать Учредительное собрание вне обстановки классовой борьбы, дошедшей до гражданской войны, то мы не знаем пока учреждения более совершенного для выявления воли народа. Но нельзя витать в области фантазий. Учредительному собранию придется действовать в обстановке гражданской войны» [8, с. 135]. «Кадеты кричат: «Вся власть Учредительному собранию», а на деле это у них значит: «Вся власть Каледину» [8, с.137]. Важным обстоятельством было и то, что в условиях 1917 г., особенно после взятия власти Советами, В.И. Ленин пересмотрел свои взгляды на Учредительное собрание. По его мнению, Россия, в своем политическом развитии, продвинулась значительно дальше, и Учредительное собрание не соответствует нынешней политической ситуации в стране. «Советы выше всяких парламентов, всяких учредительных собраний», - отмечал В.И. Ленин, «...через Учредительное собрание революции, которые были в Европе и которые свергали монархию, образовывали буржуазную республику. Такая революция, какая произошла у нас, никогда и нигде еще не была» [9, с. 140].

Учитывая популярность в широких народных массах идеи Учредительного собрания, большевики пошли на его созыв. Заседание Учредительного собрания открылось 5 января 1918 в Таврическом дворце в Петрограде. В нем участвовало 410 депутатов. Преобладали эсеры. Большевиков и левых эсеров было 155 человек (38,5\%). Председателем Учредительного собрания был избран правый эсер В. М. Чернов. 5 января 1918 г. Учредительное Собрание отказалось признать декреты II съезда Советов и «Декларацию прав трудящегося и эксплуатируемого народа». В знак протеста против решения меньшевистскоэсеровского большинства Учредительного собрания, большевики и левые эсеры покинули собрание. В ночь с 6 на 7 января ВЦИК принял декрет о роспуске Учредительного собрания.

10-18 января 1918 года в Петрограде состоялся III Всероссийский съезд Советов рабочих, солдатских и крестьянских депутатов. На съезде было представлено 317 Советов рабочих, солдатских и крестьянских депутатов и 110 apмейских, корпусных и дивизионных комитетов. 13 января к съезду присоеди- 
нились участники III Всероссийского съезда Советов крестьянских депутатов. На заключительном заседании съезда присутствовало 1587 делегатов. Съезд принял «Декларацию прав трудящегося и эксплуатируемого народа», которая стала основой будущей Конституции Советского государства. «Россия объявляется республикой Советов рабочих, солдатских и крестьянских депутатов. Вся власть в центре и на местах принадлежит этим Советам» [2]. Съезд одобрил политику ВЦИК и СНК, принял решение о том, что Российская социалистическая республика учреждается на основе добровольного союза народов России как федерация советских республик. На съезде был избран новый состав ВЦИК, в который вошли 160 большевиков, 125 левых эсеров, 2 социал-демократа интернационалиста, 3 анархиста-коммуниста, 7 эсеров-максималистов, 7 правых эсеров и 2 меньшевика. В июле 1918 г. на V Всероссийском съезде Советов рабочих, солдатских и крестьянских депутатов была принята Конституция РСФСР, которая юридически закрепила власть Советов, как органов диктатуры пролетариата, федеративное устройство государства и общественную собственность на средства производства.

В годы Гражданской войны умеренные социалисты пытались реанимировать идею Учредительного собрания, как высшего государственного органа власти российской республики. На неподконтрольной Советской власти территории России, члены бывшего Учредительного собрания попытались создать свои правительства. Летом - осенью 1918 г. на этой территории было образовано до 30 преимущественно эсеровских правительств. Среди них - Комитет членов Учредительного собрания (КОМУЧ) в Самаре, Временное сибирское правительство в Томске, Верховное управление Северной области в Архангельске и др. В сентябре 1918 г. на Государственном совещании в Уфе, Временное сибирское и другие региональные правительства объединились, избрав временную Всероссийскую директорию во главе с правым эсером Н.Д. Авксентьевым. Одной из своих задач Директория провозгласила восстановление в России Учредительного собрания. 18 ноября 1918 г. Директория была свергнута адмиралом А.В. Колчаком [11, с. 306, 307]. 30 ноября 1918 г. он приказал предать 
бывших членов Учредительного собрания военному суду. 22 декабря 1918 г. многие из них были расстреляны. В борьбе между двумя диктатурами большевиков и белого движения закончилась судьба Учредительного собрания. Таким образом, либерально-демократическая идея в России на том историческом этапе развития потерпела крах.

По мнению историка Б.Н. Миронова: «Народ свергнул либеральную демократию, разрушил основы правового государства, позволил большевикам, захватившим власть, расправиться со своими политическими противниками и установить диктатуру. Главные причины в равнодушии народа к судьбе русского парламента, в непонимании им необходимости существования парламента как гаранта против возвращения старого режима в новой форме, в слабости демократических традиций западного типа и неразвитости институтов гражданского общества. Декреты о мире, земле, рабочем контроле удовлетворили основные требования солдат, крестьян и рабочих. Поэтому, с точки зрения масс второй съезд Советов, принявший эти декреты, выполнил функцию Учредительного собрания и сделал его ненужным» [13, с. 181].

\section{«Сиисок литературы}

1. Декларация Временного Правительства о его составе и задачах». 3.03.1917 [Электронный ресурс]. - Режим доступа: http://constitution.garant.ru/history/act1600-1918/5201/

2. «Декларация прав трудящегося и эксплуатируемого народа». Принято III Всероссийским съездом Советов [Электронный ресурс]. - Режим доступа: http://constitution.garant.ru/history/act1600-1918/5320/

3. Обращение «Рабочим, солдатам и крестьянам» Принято на II Bcepocсийском съезде Советов 26 октября (8 ноября) [Электронный ресурс]. - Режим доступа: http://constitution.garant.ru/history/act1600-1918/5300/

4. «Об учреждении Совета Народных Комиссаров». Декрет II Всероссийского съезда Советов. 8 ноября (26 октября) 1917 г. [Электронный ресурс]. Режим доступа: http://constitution.garant.ru/history/act1600-1918/5301/ 
5. Постановление Временного правительства от 20 июля 1917 г. «Об утверждении раздела I положения о выборах в Учредительное собрание» [Электронный pecypc]. http://constitution.garant.ru/history/act1600-1918/5411/

6. Ленин В.И. Заседание ВЦИК 1 (14) декабря 1917 г.: Полн. собр. соч. Изд. 5. - М.: Политиздат, 1974. - Т. 35. - 600 с.

7. Ленин В.И. Об открытии Учредительного собрания: Полн. собр. соч. Изд. 5. - М.: Политиздат, 1974. - Т. 35. - 600 с.

8. Ленин В.И. Речь по вопросу об Учредительном собрании заседание ВЦИК 1 (14) декабря 1917 г.: Полн. собр. соч. - Изд. 5. - М.: Политиздат, 1974. - T. 35. $-600 \mathrm{c}$.

9. Ленин В.И. Речь на Втором Всероссийском съезде советов крестьянских депутатов 2 (15) декабря 1917 г. декабря: Полн. собр. соч. - Изд. 5. - М.: Политиздат, 1974. - Т. 35. - 600 с.

10. Ленин Тезисы об Учредительном собрании: Полн. собр. соч. - Изд. 5. М.: Политиздат, 1974. - Т. 35. - 600 с.

11. История России XX - начала XXI века / Под ред. Л.В. Милова. - М., 2007. $-958 \mathrm{c}$.

12. Конституционные проекты Временного правительства [Электронный pecypc]. - Режим доступа: http://window.edu.ru/resource/275/42275/files/gl3.pdf

13. Миронов Б.Н. Социальная история России. - Т. 2. - СПб., 1999. - 572с.

14. Новейшая история отечества XX век / Под ред. А.Ф. Киселева, Э.М. Щагина. - Т. 1. - М.: Владос, 1999. - 495 с.

15. Токарева Д. В. Конституционное законотворчество и проект основного закона Временного правительства [Электронный ресурс]. - Режим доступа: http://cyberleninka.ru/article/n/konstitutsionnoe-zakonotvorchestvo-i-proektosnovnogo-zakona-vremennogo-pravitelstva

16. Учреждения по подготовке к созыву Учредительного собрания [Электронный ресурс]. - Режим доступа: http://lawbook.online/gosudarstvaprava/uchrejdeniya-podgotovke-sozyivu-uchreditelnogo-39811.html 
Панов Владимир Николаевич - канд. ист. наук, доцент, профессор кафедры гуманитарных и социальных наук ФГБОУ ВО «Всероссийская академия внешней торговли Минэкономразвития РФ», Россия, Москва.

Panov Vladimir Nikolaevich - candidate of historical sciences, associate professor, professor of the Department of Humanities and Social Sciences FSHEI "Russian Foreign Trade Academy of the Ministry of Economic Development of the Russian Federation", Russia, Moscow. 